\title{
Analysis of Whether Cryptocurrency Like Bitcoin is Real Money from the Perspective of State Theory of Money
}

\author{
Jie Hao \\ International Business School, Shaanxi Normal University \\ Xi'an 710119, Shaanxi \\ Email: ylsyx163@126.com
}

\begin{abstract}
With the popularity of cryptocurrency like bitcoins in recent years, the social circles have been confusing whether cryptocurrency is real money essentially. Lots of voices have clarified the question from the traditional view that regards the nature of money as commodity. However, historical evidences have proved that the traditional theory deviates from the real nature of money originating from debt and is not exactly true. State Theory of Money holds the debt-based opinion on the nature of money and regards the nature of money as the debt of state, which is allowed to be the payment of tax. Therefore based on this, the paper analyzes the debt nature of money and the characteristics of cryptocurrency like bitcoins, and draws the conclusion that cryptocurrency like bitcoins is not accepted by the state as the payment of tax, not the national debt, so not the currency.
\end{abstract}

Keywords-Cryptocurrency; Bitcoin; Nature of money; National debts

\section{INTRODUCTION}

With the rapid development of Internet technology in the 21 st century, Bitcoin, a new type of "digital currency" based on open source algorithms and asymmetric encryption, was launched in 2009. Since then, other currencies of the same type, called cryptocurrencies, have arisen in the following years. These currencies represented by Bitcoin has the characteristics of decentralized issuance, fixed total amount, point-to-point transmission and distributed data storage, and provide new possibilities for transaction behaviors such as protection of property privacy, confirmation of transaction information, and management of fund accounts.

At the beginning of the birth of Bitcoin, it circulated among some virtual currency enthusiasts. By 2013, its price had exceeded 900 US dollars and began to be focused on by all walks of life. In December 2017, Bitcoin prices almost touched US\$20,000 with a market capitalization of US\$331.5 billion. And with the increasing popularity of ICO (Initial Public Offering) and more and more businesses's announcement about accepting Bitcoin, cryptocurrencies seemed to usher in a "carnival", and there was no lack of professionals who strongly advocate the "new money era." However, the "revelry" of various types of cryptocurrencies has gradually evolved into a speculative "craze". The price bubbles and illegal actions contained in it have attracted the attention of the regulators. On September 4 2017, seven ministries and commissions, including the People's Bank of China, jointly issued a document to urgently stop various types of ICO projects. They ordered them to close cryptocurrency trading websites and stop related business services. At the same time, they clearly categorized them as "illegal sale of tokens, illegal issuance of securities, and illegal fund-raising, financial fraud, pyramid selling, and other illegal activities." However, at the same time, the price of these cryptocurrencies increased rapidly in foreign markets, and the "currency" earned more and more attention.

The phenomenon has sparked a wide range of debates on "Can Bitcoin truly become a currency", and too many voice hold different perspectives based on traditional view on the nature of money, which regards money as a kind of commodity. But a lot of historical evidence have proved that money in nature is a kind of debt of state, which is also hold by State Theory of Money [1-2]. In this regard, this article intends to explore the essential attributes of cryptocurrency in the perspective of State Theory of Money, and reveal that it is not a currency but a virtual asset.

\section{LITERATURE REVIEW}

Regarding the question of "Is cryptocurrency real currency", it has to be said that Hayek's idea of currency denationalization is striking in many theories. It claims for repealing the monopoly issue rights of government, and allowing private currency issuance and free competition, [3] which is just at right moment in the background of the technical characteristics of "decentralized issue" of cryptocurrency. Hayek's successors also take the opportunity to "flag" for the "free money" and "liberal bank" views. Selgin (2013) creatively put forward the concept of "Synthetic Commodity Money", which is suitable as the base currency in the free banking mechanism because it has the dual advantage of marginal production cost greater than zero like commodity currency and not having non-monetary use like legal currency.[4] And its constant growth rate can meet the longterm needs of economic growth; more importantly, Bitcoin has all the features of "Synthetic Commodity Money", thus providing the possibility for the formation of a new type of

${ }^{1}$ Data sources: www. coinmarketcap.com 
base currency. Domestic scholars Min Min and Liu Yongming (2014), affirm Bitcoin's value base (manpower, power, and equipment costs) based on Mises' "regression theorem", and based on the BFH system claim that Bitcoin acts as a means of circulation to ensure free distribution rights of private [5].

The reason why the Austrian economists strongly advocated Bitcoin and introduced the free competition mechanism into the currency issuance field is that they regard the nature of money as a kind of commodity. Other scholars also hold a commodity-based view on the nature of money and search for the attributes of cryptocurrency along the clue of the value of commodity. Harvey (2015) pointed out that Bitcoin can exist because its users have given it value. Despite the lack of support from government and real commodities, it cannot hinder its use as a currency. Jia Liping (2013), after analyzing and affirming that Bitcoin has five major currency functions, believes that Bitcoin has the use value and value of currency and it may form a new currency system [6]. But others don't share the opinion above, although also hold the commodity-based view on the nature of money. Yermack (2014) firstly characterizes bitcoin as a speculative tool, considering that bitcoin does not have an "intrinsic value" from the perspective of the role of currency trading media, and its current value depends entirely on its role in commodities trading [7]. Li Chong(2015) emphasized that Bitcoin does not have any use value other than its exchange value, so the labor invested for its production does not form the value, and the exchange value that bitcoin currently has is only based on people's expectations to the appreciation in the future, so bitcoin and the commodity currency are essentially different, and can not be a currency; In addition, from the perspective of credit currency, bitcoin lack the support of national credit and therefore difficult to become a currency [8]. Wang Yongli (2017) follows the logic of barter, arguing that whether the base currency or the derived currency created by bank has actual value (precious metals, foreign exchange reserves, etc.) as a basis, but bitcoin does not have any value and is essentially a virtual commodity. The value created by the "mining" labor does not actually exist [9].

The reason why the above-mentioned scholars are keen to explore the value of cryptocurrency like bitcoin is that they hold the commodity-based view on the nature of the currency. However, looking back at the history of money, the commodity-based view on the nature of money that the traditional theory upholds is at a very different point from the historical fact of the origin of money. The initiator of State Theory of Money, Knapp (1924), pointed out that the creation of money originates from the requirement of the state to use its own issued debt as a public tax payment method [1]. For this reason, following this way, this paper intends to reveal the essential attributes of cryptocurrency from the perspective of the debt-based nature of currency, with combining the role of government in the origin and evolution of currency.

\section{NATURE OF CURRENCY ON THE VIEW OF STATE THEORY OF MONEY}

Traditional theories hold the view that money is essentially a kind of commodity, which is only a medium of transaction. However, State Theory of Money argues that money represents the relationship between debtor and creditor, and importantly in the most time of history, money is essentially the debt of country or state.

\section{A. The historical evidence for the nature of money}

In the early time of last time, Innes (1913) found that "hazel tally", which is a kind of wooden bar, was used to record the relationship between seller and buyer in the early commercial activities in Europe [2]. The surface of "tally" was engraved with grooves to indicate the amount of debt, and the date and debtor's name were engraved on opposite sides. And then the tally was divided into a long one and a short one, and the grooves were also divided into two parts. The longer part was called the "stock" held by creditors, and the shorter one was called the "stub" held by the debtor, and when the two parts were rejoined, the creditor's rights and debts were confirmed. Such "tally" were widely circulated and transferred, and people can use "stock" to pay for goods or pay off other debts, and in some parts of England and France even once emerged some special markets for settlements and exchanges for "tally".

The most important point is that in a long term in history, "tally" were issued by British government as its debt to "buy" various goods and services, and then were withdrawn as payment of tax. This condition continued until 1834 when all the "tally" in British treasury were burned occasionally [10].

Expect for "tally" in Europe, the similar examples include the Babylonian clay version 5,000 years ago, which was called "shubati" (means "receive"), and the name of debtor and creditor, the date of debt, the amount of grain and the word "shubati" were recorded on the version. The clay versions would be preserved in temple or be encased in casket, and the clay versions in casket can be circulated in market, and when the casket was opened, the debt recorded on clay version could be confirmed, and at the same time the clay version would be destroyed. And what can not be ignored is that the information about the amount of grain was recorded with the unit of "shekel" and "mina" created by the authorities in temple, and the unit were used widely in markets [11].

Therefore, the evidences from history prove that money is essentially the relationship between debtor and creditor, which is related to country or state at a very large extent.

\footnotetext{
${ }^{1}$ Selgin pointed out that although the total amount of Bitcoin will eventually be fixed at 21 million, before reaching this number, its production speed has always been maintained at a preseted stable rate due to the difficulty of "mining".

${ }^{1}$ The BFH system refers to the concept of a currency system proposed by Black, Fama and Hall that separates the means of circulation from the measure of value in order to solve the "Hahn puzzle". In terms of issuance, the market competition mechanism is introduced to eliminate the monopoly position of the government.
} 


\section{B. The national logic in the origin of money}

It has been proved that money essentially embodies social relations such as "claim" and "credit", which most produced from marriage, blood hatred, loan and others, and this type of social relationship is independent of the production and exchange of goods [12]. Here, the most obvious point is that social relations such as "claims" and "credit" are the debtclaims relations between various subjects of society, and this social relationship does not presuppose the existence of a trading market. Furthermore, Innes (1913) pointed out that in the early days of civilization, humankind paid off their debts by paying "wergild" to the victim and his family (it usually because of blood hatred), thereby reducing the violent conflict between people. However, due to the lack of accounting units at the time, "wergild" was presented as something that was easily accessible and useful to the victim [2].

On the history, the "wergild" would also be levied to the public for possible violations, in order to repay the debt to the injured person or family because of the violation. And it would form a record of "wergild", which was handed down to the next generation by a specific person [12]. Furthermore, the related research shows that the "wergild" was levied by the authority state with human development, and the scope of the expropriation was extended to a wider field, which formed the embryonic form of the national tax [13]. It is not difficult to see that the "wergild", as a kind of public debt, was expropriated by the state, so the national tax can be understood in essence as a kind of public debt to the government.

It is obvious that expropriation of tax would be easier through something unified and standard, in contrast to through various goods. Actually, in the history, sovereign countries have the right to decide what can be used to fulfill tax liabilities, [14] and the tax payment method accepted by the national tax department is the currency form recognized by a country, [10] which can be proved by the various coins or cash issued by governments in history.

For this reason, as Knapp believes, the state issues its own "IOUs" and uses it as an approved tax payment method, that is, the state allows the public to pay taxes with their own "IOUs". As a result, the country's "IOUs" has become a form of currency recognized by the state, and its role as a tax payment guarantees its authority as a national currency, and generates a great deal of public demand for national currency, making it widely used in settlement of private debt. This is the assertion of "Tax Drive Money" in State Theory of Money. The selfevident logic is that the issuer of the debt must allow his creditors to use the debt to pay off the creditor's other debt to the debtor [10]. For this reason, since taxes are the debts of the public to the government, the government (nation) must allow the public to fulfill its tax obligations in the form of the national currency issued by the government itself.

Therefore, based on the analysis above, money, or sovereign money strictly speaking, is essentially the debt of state under the guarantee from the tax mechanism, which creates the demand of sovereign money among public for liquidation of private debts, like the view of State Theory of Money.

\section{ANALYSIS OF WHETHER CRYPTOCURRENCY LIKE BITCOIN IS REAL MONEY}

Cryptocurrency has received sustained buzz in recent years, and most scholars have discussed the material cost in the production process and the features in issuance of decentralization and fixed total amount, and discussed whether it has value base and credit support. The fact that cryptocurrency like bitcoin is accepted by some businesses and partially fulfills its currency functions also makes some people look forward to their potential as future currencies. However, whether it is from the discussion of its value or from the perspective of monetary functions, it lacks the persuasive power that conforms to the historical logic. Therefore, it is necessary to develop the analysis of cryptocurrency like bitcoin based on State Theory of Money mentioned above.

According to the analysis above, the nature of money is a kind of debt of state that guaranteed by tax mechanism, and can be transferred widely in public to pay off private liabilities. However, the characteristics of decentralized issuance of cryptocurrencies make it free to compete in the production ("mining"), and it is not the debt issued by the "diggers", nor is it anyone's debt, which can be clarified through simple balance sheet.

TABLE I. BALANCE SHEET OF “DIGGER”

\begin{tabular}{|c|c|}
\hline Asset & Liability \\
\hline Fixed Asset and Other Asset - \\
\hline Bitcoins + \\
\hline
\end{tabular}


TABLE II. BALANCE SHEET OF OTHERS WHO BUY BITCOINS

\begin{tabular}{c|c} 
Asset & Liability \\
\hline Fiat Money - \\
\hline Bitcoins + & \\
\hline
\end{tabular}

TABLE III. BALANCE SHEET OF BUSINESS ACCEPTING BITCOINS

\begin{tabular}{|c|c|} 
Asset & Liability \\
\hline Goods or Services - & \\
\hline Bitcoins + & \\
\hline
\end{tabular}

Through Table I, taking bitcoin as an example, a "digger" buys electricity power and devices like mining machine before "mining" bitcoins, and when the bitcoins are produced out they are recorded as a kind of asset rather than debt, which will give a right to the "digger" because it can be exchanged to fiat money that is more than the "digger" invests initially. So it is obvious that cryptocurrency like bitcoin is not debt of "diggers". According to Table II and III, in the balance sheet of other people who buy bitcoins or the businesses that accept bitcoins as payment method, bitcoins are also recorded as a kind of asset but not liability. So no matter what kind of situations, cryptocurrency like bitcoins is not debt for anyone, and for this reason, it will not become currency.

Therefore, based on the analysis above, the phenomenon that some businesses accept bitcoins as the payment for purchasing is only the exchange between asset and another one, which seems a kind of example for "barter" but is not based on debt, or money strictly speaking.

From the perspective of countries, with no country accepting it as the tax payment method, cryptocurrency like bitcoins is difficult to become a unit symbol for measuring public tax liabilities, nor can it appear as an "identity" of national debt, and thus it lacks the guarantee of a state commitment that is accepted as a form of tax reimbursement. Therefore, it will be difficult to become the national currency in the liquidation of private debts. Just like the opinion of some scholars, money is a token of government and an integral part of regime, but the characteristic of not being issued centrally by government of cryptocurrency makes it lack of national credit support, and prevent it to play a monetary function. [15] [16] As for the facts that several countries like German announce accepting bitcoins as the payment of tax, that actually is only the surface because the bitcoins received by government are usually transferred to fiat money, and then the fiat money is still the real payment for tax liability eventually, so the cryptocurrency like bitcoins still can not be accepted by state, and could not be the debt of state, and therefore is not the national currency.

\section{CONCLUSION}

On the view of State Theory of Money, in the origin of currency, the measurement of tax liabilities by the state plays a key role; the currency also means national debt because the state accepts it as a form of tax payment. This taxation mechanism also further ensures that the state debt is widely acceptable in the liquidation of private debt. Anyone "mining", buying or accepting cryptocurrency like bitcoins records them as an kind of asset, and most importantly the state never accepts them as the payment of tax liability, therefore they are not the debt of state and will not become national currency. 


\section{REFERENCES}

[1] Knapp G F. The State Theory of Money [M]. London: Macmillan \& Company Limited, St. Martin's Street, 1924.

[2] A. Mitchell Innes. What is Money? [J]. The Banking Law Journal, 1913(5): 377-408.

[3] F. A. Hayek. Denationalisation of Money -The Argument Refined [M]. London: The Institute of Economic Affairs, 1990.

[4] Selgin G. Synthetic commodity money [J]. Journal of Financial Stability, 2013, 17: 92-99.

[5] Min Min \& Liu Yongming The Value Origins and Money Functions for Internet Currency- A Bitcoin Perspective [J]. Academic Monthly, 2014(12): 97-108. (In Chinese)

[6] Jia Liping. The Theory, Practice and Influence of Bitcoin [J]. International Finance Research, 2013(12):14-25. (In Chinese)

[7] Yermack D. Is bitcoin a real currency? An Economic Appraisal [J]. Social Science Electronic Publishing, 2013: 31-43.

[8] Li Chong. Will Bitcoin Become a Currency? [J]. Contemporary Economic Research, 2015(4): 60-65. (In Chinese)

[9] Wang Yongli, The Nature of Money and Bitcoin, Central Bank Digital Currency, 2017.9.16, https://mp.weixin.qq.com/s. (In Chinese)

[10] L. Randall Wray, Translated by Liu Xinhua. Interpretation of Modern Currency: Realizing Full Employment and Price Stability [M]. Beijing: Central Compilation and Translation Press, 2011.6, pp. 47-54.

[11] David Graber, Translated by Sun Tan, Dong Ziyun. Debt: The First 5000 Years [M]. Beijing: CITIC Press, 2012.11, pp.38-39. (In Chinese)

[12] L. Randall Wray (2014). From the State Theory of Money to Modern Money Theory: An Alternative to Economic Orthodoxy. Levy Economics Institute Working Paper. No. 792. New York: Levy Economics Institute of Bard College.

[13] Liu Xinhua, Xian Wen. The Essence of Money: the Debate between Orthodoxy and Heterodoxy [J]. Comparison of Economic and Social Systems, 2010 (6): 174-181. (In Chinese)

[14] L. Randall Wray. The Nature of Money: Post-Keynesian Viewpoints [J]. Political Economy Review, 2012(1): 172-175. (In Chinese)

[15] Li Yiqi. Talk about Digital Currency. 2017.9.12, https://mp.weixin.qq.com/s. (In Chinese)

[16] Sheng Songcheng, Yu Chun. The Idea of Denationalisation of Money and Utopia of Bitcoin [J]. China Finance, 2014(7):32-34.(In Chinese) 